\title{
Syntheses, Characterization and Biological Activity of Coordination Compounds of 3-Hydroxy-2-methyl-4H-pyran-4-one and Its Mixed Ligand Complexes with 1,2-Diaminocyclohexane
}

\author{
Temitayo 0. Aiyelabola \\ Department of Chemistry, Obafemi Awolowo University, Ile-Ife, Nigeria \\ Email: taiyelabola@gmail.com
}

How to cite this paper: Aiyelabola, T.O. (2021) Syntheses, Characterization and Biological Activity of Coordination Compounds of 3-Hydroxy-2-methyl-4Hpyran-4-one and Its Mixed Ligand Complexes with 1,2-Diaminocyclohexane. Advances in Biological Chemistry, 11, 106-125. https://doi.org/10.4236/abc.2021.113008

Received: December 22, 2020

Accepted: May 11, 2021

Published: May 14, 2021

Copyright (อ 2021 by author(s) and Scientific Research Publishing Inc. This work is licensed under the Creative Commons Attribution International License (CC BY 4.0).

http://creativecommons.org/licenses/by/4.0/ (c) (i) Open Access

\begin{abstract}
Coordination compounds of 3-hydroxy-2-methyl-4H-pyran-4-one with iron(III), cobat(III) and chromium(III) were synthesized with M:L (1:2). Mixed ligand coordination compounds of 3-hydroxy-2-methyl- $4 \mathrm{H}$-pyran-4-one and 1,2-diaminocyclohexane using the same metal ions were also synthesized M:L1:L2 (1:1:1) where L1 is 3-hydroxy-2-methyl-4H-pyran-4-one and L2 is 1,2-diaminocyclohexane. The coordination compounds obtained were characterized using electronic and infrared spectral analyses, magnetic susceptibility and percentage metal analysis. They were also evaluated for their cytotoxic and antioxidant activities. The result obtained suggested that octahedral geometry was obtained for all the compounds, as a result of additional two molecules of the solvent coordinated to the metal ions. Both the primary and secondary ligands coordinated in a bidentate fashion. The synthesized compounds exhibited moderate cytotoxicity, although none was as active as the standard. The cobalt(III) mixed ligand complex elicited the highest activity. The synthesized compounds all exhibited good to moderate antioxidant activity.
\end{abstract}

\section{Keywords}

Coordination Compounds, Cytotoxicity, Antioxidant, Mixed Ligand Complexes, 3-Hydroxy-2-methyl-4H-pyran-4-one 1,2-Diaminocyclohexane

\section{Introduction}

The application of coordination compounds in chemistry and technology is 
many, varied and well established. Coordination compounds in the form of mixed ligand complexes have found usage commercially in medicine. These include cis-platin and auranofin used in anticancer chemotherapy and rheumatoid arthritis, respectively [1] [2] [3].

Cancer is a leading cause of death worldwide. It accounted for 8.2 million as deaths; around $22 \%$ of all deaths not related to communicable diseases. Deaths from cancer worldwide are projected to continue rising, with an estimated 13.1 million deaths in 2030 (about a 70\% increase) [4] [5]. Chemotherapy with cytotoxic drugs serves as the main treatment modality for certain types of cancer [6] [7]. Studies have shown that the presence of increased level of exogenous antioxidants prevents certain types of free radical damage that has been associated with cancer development [8]. Previous data also suggested that certain antioxidants selectively inhibit the growth of tumor cells, induce cellular differentiation, and alter the intracellular redox state, thereby enhancing the effect of cytotoxic therapy [8]-[13]. Additionally, research has shown that antioxidants may also reduce certain types of toxicity associated with chemotherapeutic treatments [8]-[13]. However, it was inferred that they may do so by interfering with the efficacy of conventional therapy. Therefore, antioxidant supplementation during chemotherapy may compensate for treatment of cancer-induced antioxidant depletion, alleviate side effects and also maintain or improve general health and well-being [14]. A consequence of this is that drugs with antioxidant mechanisms are being widely proposed as starting point for the development of new therapeutic interventions in several pathological disorders associated with oxidative damage, caused by reactive oxygen species (ROS), such as cancer [15]. The search for metal-derived antioxidants has therefore received much attention in more recent times.

Phenolic compounds are a class of very important compounds with multiple biological functions including antioxidant activity which have been reported to be related to the radical scavenging ability of the hydroxyl group. A number of studies have reported the relative correlation between phenol and antioxidant activity [16] [17]. 3-Hydroxy-2-methyl-4 $H$-pyran-4-one (L1), is a naturally occurring organic compound bearing a phenolic substituent, and it is used primarily as a flavor enhancer. Reports have shown that its derivatives exhibited limited in vitro antiproliferative activity towards cancer cells lines, with the mechanism of activity suggested as inducing apoptosis in the cancer cells [18] [19]. 1,2-Diaminocyclohexane (L2) is a compound that has found usage in the syntheses of anticancer drugs. It mixed ligand complexes are currently used commercially for the treatment of cancer and cisplatin-resistant tumours [20] [21]. These include tetraplatin $\left[\mathrm{PtCl}_{4}(\mathrm{~L} 2)\right]$ and oxaliplatin [Pt(L2)(oxalate)]. Earlier workers in an attempt to develop novel metal-based drugs with a different therapeutic profile to cis-platin, synthesized a series of tin compounds containing the L2, including the Sn analogue of tetraplatin. The result obtained suggested the complexes exhibited reasonable activity with increased differential toxicity 
across the cell line panel [22].

As a consequence it was considered to synthesize coordination compounds of 3-hydroxy-2-methyl-4H-pyran-4-one (L1) Figure 1, with iron(III), cobalt(III) and chromium(III). Additionally its mixed ligand complex with 1,2-diaminocyclohexane (L2), Figure 1, as the secondary ligand was synthesized. These were then characterized using electronic, infrared spectroscopy, magnetic susceptibility measurement and percentage metal analysis. The synthesized complexes were thereafter investigated for their cytotoxic activity using brine shrimp lethality assay, and antioxidant activity.

\section{Materials and Method}

\subsection{General}

All materials used are of high analytical grade. Melting points were determined in an open capillary tube on a Gallenkamp (Variable heater) melting point apparatus. The infrared spectra of all synthesized products and their ligands were obtained using Agilent Cary 630 FTIR. Magnetic susceptibility measurement of the metal complexes was using a MSB Mk1 magnetic susceptibility balance, Sherwood Scientific and corrected with. The electronic spectra, of all the compounds, were obtained in solution, in the wavelength range $400-1000 \mathrm{~nm}$ using 1800 Shimadzu ultra-violet spectrophotometer. The metal analyses for all synthesized compounds were obtained using titrimetric method using EDTA. The cytotoxic analysis of the compounds was carried out using brine shrimp lethality assay. The antioxidant activity for all the complexes was carried out using four assays namely; nitric oxide radical inhibition, ferric reducing antioxidant power (FRAP), ferrous ion-chelating ability and cupric ion reducing antioxidant capacity assays. The compounds were synthesized using an adaptation of previous method [23]. The equations of the reactions are given in Equations (1)-(6).

$$
\begin{aligned}
& \mathrm{FeCl}_{2}+2(\mathbf{L 1})+\mathrm{H}_{2} \mathrm{O}_{2} \rightarrow\left[\mathrm{Fe}(\mathbf{L 1})_{2}\left(\mathrm{H}_{2} \mathrm{O}\right)_{2}\right] \text { (Compound 1) } \\
& \mathrm{FeCl}_{2}+\mathbf{L 1}+\mathbf{L} \mathbf{2}+\mathrm{H}_{2} \mathrm{O}_{2} \rightarrow\left[\mathrm{Fe}(\mathbf{L 1})(\mathbf{L} 2)\left(\mathrm{H}_{2} \mathrm{O}\right)_{2}\right] \text { (Compound 2) } \\
& \mathrm{CoCl}_{2}+2 \mathbf{L 1}+\mathrm{H}_{2} \mathrm{O}_{2} \rightarrow\left[\mathrm{Co}(\mathbf{L 1})_{2}\left(\mathrm{H}_{2} \mathrm{O}\right)_{2}\right] \text { (Compound 3) } \\
& \mathrm{CoCl}_{2}+\mathbf{L 1}+\mathbf{L} 2+\mathrm{H}_{2} \mathrm{O}_{2} \rightarrow\left[\mathrm{Co}(\mathbf{L 1})(\mathbf{L} 2)\left(\mathrm{H}_{2} \mathrm{O}\right)_{2}\right] \text { (Compound 4) }
\end{aligned}
$$

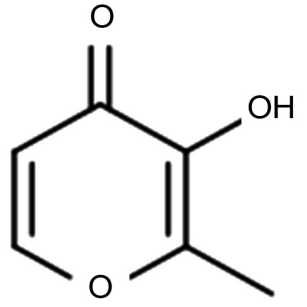

(a)

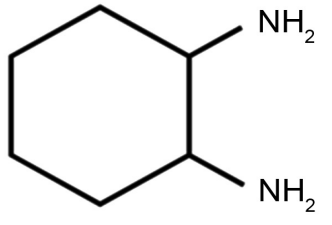

(b)

Figure 1. (a) L1 = 3-hydroxy-2-methyl-4H-pyran-4-one; (b) L2 = 1,2-diaminocyclohexane. 


$$
\begin{gathered}
\mathrm{CrCl}_{3}+2 \mathbf{L 1} \rightarrow\left[\mathrm{Cr}(\mathbf{L 1})_{2}\left(\mathrm{H}_{2} \mathrm{O}\right)_{2}\right] \text { (Compound 5) } \\
\mathrm{CrCl}_{3}+\mathbf{L 1}+\mathbf{L 2} \rightarrow\left[\mathrm{Cr}(\mathbf{L 1})(\mathbf{L 2})\left(\mathrm{H}_{2} \mathrm{O}\right)_{2}\right] \text { (Compound 6) }
\end{gathered}
$$

where: L1 = 3-Hydroxy-2-methyl-4H-pyran-4-one; L2 = 1,2-diaminocyclohexane.

\subsection{Syntheses of Compounds}

1) Synthesis of Compound 1: An aqueous solution of Iron(II) chloride hexahydrate $(1.59 \mathrm{~g}, 0.01 \mathrm{M})$ was poured into a flat bottom flack and was heated with stirring. To this was added, drop-wise, hydrogen peroxide $(0.36 \mathrm{~g}, 0.01 \mathrm{M})$. Aqueous ethanolic solution of 2-hydroxy-2-methyl-4H-pyran-4-one (2.36 g, 0.02 $\mathrm{M})$ was added drop-wise. The reaction mixture was heated for $2 \mathrm{hr}$, during which a pale brown precipitate was obtained. This was filtered washed first with methanol then diethyl ether and dried in a desiccator. Yield: $2.58 \mathrm{~g}$ (75.36\%), M.pt/d.t: $135^{\circ} \mathrm{C}-136^{\circ} \mathrm{C}$ (d), metal composition (\%): 15.73 (found); 16.03 (calcd). The complex was soluble in water but sparingly soluble in ethanol, methanol. Similar procedure was used for the preparation of the under listed complexes.

2) Synthesis of Compound 2: Iron(II) chloride hexahydrate (1.58 g, $0.01 \mathrm{M})$ in a flat bottom flask to which was added hydrogen peroxide $(0.35 \mathrm{~g}, 0.01 \mathrm{M})$, 2-hydroxy-2-methyl-4H-pyran-4-one (1.18 g; $0.01 \mathrm{M})$ and 1,2-diaminocyclohexane $(0.80 \mathrm{~g}, 0.01 \mathrm{M})$ heated with stirring. This gave a dark green precipitate. Yield: $2.29 \mathrm{~g}(69.25 \%), \mathrm{M} . \mathrm{pt} / \mathrm{d} . \mathrm{t}: 221^{\circ} \mathrm{C}-222^{\circ} \mathrm{C}$, metal composition (\%): 17.02 (found); 16.61 (calcd). The complex was soluble in water but sparingly soluble in ethanol, methanol.

3) Synthesis of Compound 3: Cobalt(II) chloride hexahydrate $(1.61 \mathrm{~g}, 0.01 \mathrm{M})$ to which, hydrogen peroxide $(0.36 \mathrm{~g}, 0.01 \mathrm{M})$ and 2-hydroxy-2-methyl- $4 \mathrm{H}$ pyran-4-one (2.38 g; $0.02 \mathrm{M})$ was added and heated with stirring. This gave a light pink precipitate. Yield: $2.49 \mathrm{~g}(71.89 \%)$, M.pt/d.t: $182^{\circ} \mathrm{C}-183^{\circ} \mathrm{C}$, metal composition (\%.): 17.23 (found); 17.00 (calcd.). The complex was soluble in water but sparingly soluble in ethanol, methanol.

4) Synthesis of Compound 4: Cobalt(II) chloride hexahydrate (1.63 g, $0.01 \mathrm{M})$, hydrogen peroxide $(0.34 \mathrm{~g}, 0.01 \mathrm{M})$ and 2-hydroxy-2-methyl-4H-pyran-4-one $(1.18 \mathrm{~g} ; 0.01 \mathrm{M})$ and 1,2-diaminocyclohexane $(1.18 \mathrm{~g} ; 0.01 \mathrm{M})$ gave a pink precipitate. Yield: $2.42 \mathrm{~g}(73.31 \%)$, M.pt/d.t: $112^{\circ} \mathrm{C}-113^{\circ} \mathrm{C}(\mathrm{d})$, metal composition (\%.): 17.44 (found); 17.61 (calcd.). The complex was soluble in ethanol, methanol but sparingly soluble in water.

5) Synthesis of Compound 5: Chromium(III) chloride hexahydrate (1.58 g, $0.01 \mathrm{M})$ in a flat bottom flask to which was added and 2-hydroxy-2-methyl$4 H$-pyran-4-one $(2.38 \mathrm{~g} ; 0.02 \mathrm{M})$ heated with stirring. This gave a dark green precipitate. Yield: $2.33 \mathrm{~g}(68.52 \%), \mathrm{M} . \mathrm{pt} / \mathrm{d} . t: 164^{\circ} \mathrm{C}-165^{\circ} \mathrm{C}(\mathrm{d})$, metal composition (\%.): 15.56 (found); 15.29 (calcd.). The complex was soluble in water but sparingly soluble in ethanol, methanol.

6) Synthesis of Compound 6: Chromium(III) chloride hexahydrate (1.58 g, 0.01 
$\mathrm{M})$ in a flat bottom flask to which was added 2-hydroxy-2-methyl-4H-pyran-4-one (1.18 g; 0.01) and 1,2-diaminocyclohexane (1.80 g, $0.01 \mathrm{M})$ heated with stirring. This gave a dark green precipitate. Yield: $1.72 \mathrm{~g}(62.20 \%)$, M.pt/d.t: $127^{\circ} \mathrm{C}$ $128^{\circ} \mathrm{C}$ (d), metal composition (\%.): 15.80 (found); 15.85 (calcd.). The complex was soluble in ethanol, methanol but sparingly soluble in water.

\subsection{Cytotoxicity Bioassay}

The procedure used was modified from the assay described by Solis et al. [24]. Brine shrimp (Artemia salina) were hatched from shrimp eggs in a conical shaped vessel $(1 \mathrm{~L})$. Subsequently the vessel was filled with sterile, artificial seawater under continuous aeration for $48 \mathrm{~h}$. After hatching, active nauplii free from eggshells were collected from brighter portion of the hatching chamber. These were employed for the assay. Ten nauplii were drawn through a Pasteur pipette and placed in each vial containing $4.5 \mathrm{mg} / \mathrm{L}$ of brine solution. In each experiment, different volumes of the sample chelates were added to $4.5 \mathrm{~mL}$ of brine solution. This produced different concentrations of 20,40,60, 80 and 100 $\mu \mathrm{g} / \mathrm{mL}$. Solutions were maintained at room temperature for $24 \mathrm{~h}$ under light. The surviving larvae were counted. Experiments were conducted along with the control (vehicle treated), of the test substances in a set of three tubes per dose. Estimation of the $\mathrm{LC}_{50}$ values was estimated using probit analysis on a USEPA computer program.

\subsection{Antioxidant Activity}

The antioxidant activity for all the compounds was carried out using four assays.

\subsubsection{Inhibition of Nitric Oxide Radical}

The inhibition nitric oxide radical activity of the synthesized compounds was carried out according to the method of Green et al., (1982) as described by Marcocci et al. (1994) [25]. The reaction mixture, containing $0.1 \mathrm{ml}$ of different concentrations $(10,5,2.5,1.25,0.625,0.3125 \mathrm{mg} / \mathrm{ml})$ of the sample and $0.9 \mathrm{ml}$ of sodium nitroprusside $(2.5 \mathrm{mM})$ in phosphate buffer saline was incubated under illumination for 150 minutes. After incubation, $0.5 \mathrm{ml}$ of $1 \%$ sulphanilamide in $5 \%$ phosphoric acid was added and incubated in the dark for $10 \mathrm{~min}$., followed by addition of $0.5 \mathrm{ml} 0.1 \% \mathrm{NED}$ (N-1-napthyl ethylenediamine dihydrochloride). The absorbance of the chromophore formed was measured at $546 \mathrm{~nm}$ (Marcocci et al., 1994) [25]. The percentage inhibition of nitric oxide radical formation was calculated as expressed below.

$$
\text { \%inhibition }=\left[\left(A_{\text {control }}-A_{\text {sample }}\right) / A_{\text {control }}\right] \times 100
$$

where $A_{\text {control }}=$ absorbance of control sample and $A_{\text {sample }}=$ absorbance of a tested sample.

\subsubsection{Ferrous Ion-Chelating Ability Assay}

The ferrous ion-chelating (FIC) assay was carried out according to the method of Singh and Rajini, 2004 with some modifications [26]. Solutions of $2 \mathrm{mM}$ 
$\mathrm{FeCl}_{2} \cdot 4 \mathrm{H}_{2} \mathrm{O}$ and $5 \mathrm{mM}$ ferrozine were diluted 20 times. An aliquot $(1 \mathrm{ml})$ of different concentrations of sample was mixed with $1 \mathrm{ml} \mathrm{FeCl} \cdot 4 \mathrm{H}_{2} \mathrm{O}$. After $5 \mathrm{~min}$ incubation, the reaction was initiated by the addition of ferrozine $(1 \mathrm{ml})$. The mixture was shaken vigorously and after a further $10 \mathrm{~min}$ incubation period the absorbance of the solution was measured spectrophotometrically at $562 \mathrm{~nm}$. The percentage inhibition of ferrozine- $\mathrm{Fe}^{2+}$ complex formations was calculated by using the formula:

$$
\text { Chelating effect \% }=\left[\left(A_{\text {control }}-A_{\text {sample }}\right) / A_{\text {control }}\right] \times 100
$$

where $A_{\text {control }}=$ absorbance of control sample (the control contains $\mathrm{FeCl}_{2}$ and ferrozine, complex formation molecules) and $A_{\text {sample }}=$ absorbance of a tested sample.

\subsubsection{Determination of Ferric Reducing Antioxidant Power (FRAP)}

The FRAP assay uses antioxidants as reductants in a redox-linked colorimetric method with absorbance measured with a spectrophotometer (Benzie and Strain, 1999) [27]. A $300 \mathrm{mmol} / \mathrm{L}$ acetate buffer of $\mathrm{pH} 3.6,10 \mathrm{mmol} / \mathrm{L}$ 2,4,6-tri-(2-pyridyl)-1,3,5-triazine and $20 \mathrm{mmol} / \mathrm{L} \mathrm{FeCl}_{3} \cdot 6 \mathrm{H}_{2} \mathrm{O}$ were mixed together in the ratio of 10:1:1 respectively, to give the working FRAP reagent. A 50 $\mu \mathrm{l}$ aliquot of the sample at $0.1 \mathrm{mg} / \mathrm{ml}$ and $50 \mu \mathrm{l}$ of standard solutions of ascorbic acid $(20,40,60,80,100 \mu \mathrm{g} / \mathrm{ml})$ was added to $1 \mathrm{ml}$ of FRAP reagent. Absorbance measurement was taken at $593 \mathrm{~nm}$ exactly 10 minutes after mixing against reagent blank containing $50 \mu \mathrm{l}$ of distilled water.

All measurements were taken at room temperature with samples protected from direct sunlight. The reducing power was expressed as equivalent concentration (EC) which is defined as the concentration of antioxidant that gave a ferric reducing ability equivalent to that of the ascorbic acid standard.

\subsubsection{CUPRAC Assay}

In order to determine the cupric ions $\left(\mathrm{Cu}^{2+}\right)$ reducing ability of compounds, the method of Apak et al. was used with little modification as described by Gulcin [28] [29]. $0.25 \mathrm{ml} \mathrm{CuCl}_{2}$ solution (0.01 M), $0.25 \mathrm{ml}$ ethanolic neocuproine solution $\left(7.5 \times 10^{-3} \mathrm{M}\right)$, and $0.25 \mathrm{ml} \mathrm{CH}_{3} \mathrm{COOH}_{4}$ buffer $(1 \mathrm{M})$ were added to a test tube, followed by mixing with $0.25 \mathrm{ml}$ of extracts. The total reaction volume was adjusted to $2 \mathrm{ml}$ with distilled water, and the solution was mixed well. The tubes were stoppered and kept at room temperature for $30 \mathrm{~min}$, and absorbance was measured at $450 \mathrm{~nm}$. Increased absorbance indicates increased reduction capability which is express as Trolox equivalent (TEAC) using Trolox as standard.

\section{Results and Discussion}

\subsection{FTIR}

\subsubsection{FTIR of the Ligands}

1) The FTIR spectrum of the primary ligand L1, exhibited a sharp band at 
$3330 \mathrm{~cm}^{-1}$. This is indicative of the $\mathrm{O}-\mathrm{H}$, stretching frequency of the phenolic substituent of the ligand. Supporting this were bands observed at 2100 and 1250 $\mathrm{cm}^{-1}$, which were assigned to $v(\mathrm{C}-\mathrm{OH})$ and $\delta(\mathrm{O}-\mathrm{H}) \mathrm{Ar}$, respectively [30] [31]. The spectrum also showed bands at 1650 and $1530 \mathrm{~cm}^{-1}$ were attributed to $v(\mathrm{C}=$ $\mathrm{O})+v(\mathrm{C}=\mathrm{C})$. This is suggestive of conjugation between the aldehyde moiety of $\mathrm{L} 1$ and the aromatic $\mathrm{C}=\mathrm{C}$. Bands observed at 1630 and $1450 \mathrm{~cm}^{-1}$ were ascribed to $v(\mathrm{C}=\mathrm{O})+\delta(\mathrm{C}-\mathrm{H})$. The band observed at $1230 \mathrm{~cm}^{-1}$ was assigned to $v(\mathrm{C}-\mathrm{O}-\mathrm{C})$, from the ether substituent of the ligand [30] [31].

2) Ligand L2: The spectrum of the secondary ligand $L 2$, showed a broad band at $3340 \mathrm{~cm}^{-1}$. This is attributable to the $v(\mathrm{~N}-\mathrm{H})$. Two medium bands observed at 1590 and $1420 \mathrm{~cm}^{-1}$ were ascribed to $\delta(\mathrm{N}-\mathrm{H})$ [30] [31]. A weak band at 1180 $\mathrm{cm}^{-1}$ was assigned to $v(\mathrm{C}-\mathrm{N})$ [30] [31].

\subsubsection{FTIR of the Complexes}

1) Compound 1: On coordination to the metal ion, the $\mathrm{O}-\mathrm{H}$ stretching frequency of the phenolic substituent of the ligand shifted to higher frequency by $28 \mathrm{~cm}^{-1}$ at $3358 \mathrm{~cm}^{-1}$. Another weak band was also observed at $3242 \mathrm{~cm}^{-1}$ (Figure 2). Both bands suggested possible intermolecular hydrogen bonding [30] [31] [32]. Two bands observed at 3768 and $3432 \mathrm{~cm}^{-1}$ were assigned to hydroxyl stretching frequency, indicative of probable intermolecular hydrogen bonding. The bands attributed to $v(\mathrm{C}=\mathrm{O})+v(\mathrm{C}=\mathrm{C})$ shifted to lower and higher frequencies at 1613 and $1558 \mathrm{~cm}^{-1}$ in this complex [30] [31] [32]. This therefore served as evidence for the coordination of the oxygen atom of the aldehyde moiety to the metal ion. In support of this was the shift observed for the $v(\mathrm{C}=\mathrm{O})+\delta(\mathrm{C}-\mathrm{H})$ to $1457 \mathrm{~cm}^{-1}$ [30] [31] [32]. Another band observed at $1394 \mathrm{~cm}^{-1}$ was attributed $\delta(\mathrm{O}-\mathrm{H}) \mathrm{Ar}$, of the phenol substituent of the ligand. A shift of 52 and 32

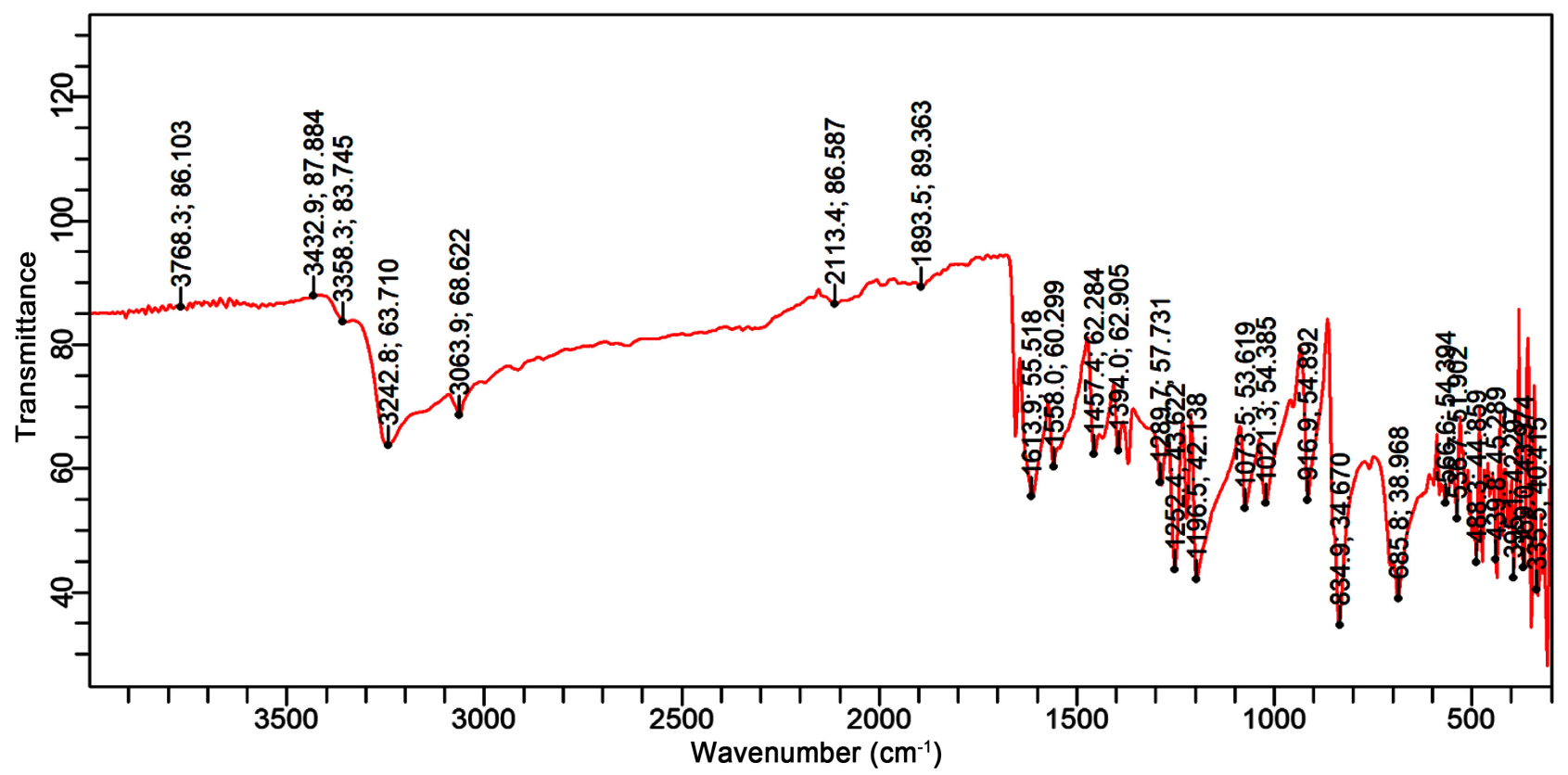

Figure 2. FTIR spectrum of compound 1. 
$\mathrm{cm}^{-1}$ was observed for the $v(\mathrm{C}-\mathrm{O}-\mathrm{C})$. This may be attributable to the elongation of the bonds in this particular substituent as a result of coordination of substituents adjacent to it. This suggests the rearrangement of the ring as a result of coordination. In addition to the bands observed in the free base ligand, two bands were observed at 1073 and $1021 \mathrm{~cm}^{-1}$ and were assigned to $\delta(\mathrm{O}-\mathrm{H})$. Metal-oxygen frequency band was observed at $685 \mathrm{~cm}^{-1}$, which is an additional support of coordination of the ligand to the metal ion [32].

2) Compound 2: The spectrum of compound 2 elicited two broad frequency bands at 3779 and $3570 \mathrm{~cm}^{-1}$ (Figure 3). The latter frequency band was attributed to the phenolic $\mathrm{O}-\mathrm{H}$, which shifted to higher frequency by $270 \mathrm{~cm}^{-1}$, in comparison with that obtained for ligand L1. Therefore, this served as indication of the coordination of the oxygen atom of the phenol substituent to the metal ion [32]. This was supported by the $\delta(\mathrm{O}-\mathrm{H}) \mathrm{Ar}$ which shifted to $1397 \mathrm{~cm}^{-1}$ in the spectrum of compound 2 . On the other hand, the former $v(\mathrm{O}-\mathrm{H})$ frequency band suggested the presence and coordination of an hydroxyl substituent in addition to the phenolic $\mathrm{OH}$ of the primary ligand [30]. This was supported by the band observed at $1080 \mathrm{~cm}^{-1}$ assignable to $\delta(\mathrm{O}-\mathrm{H})$ [30] [31] [32]. On coordination the $v(\mathrm{C}=\mathrm{O})+v(\mathrm{C}=\mathrm{C})$ frequency band shifted to 1651 and $1574 \mathrm{~cm}^{-1}$. The $v(\mathrm{C}=\mathrm{O})+\delta(\mathrm{C}-\mathrm{H})$ shifted to 1606 and $1457 \mathrm{~cm}^{-1}$. Evidence of the coordination of the secondary ligand $\mathrm{L} 2$ to the metal ion was given by the frequency bands observed at 3410 and $1181 \mathrm{~cm}^{-1}$, which were attributed to $v(\mathrm{~N}-\mathrm{H})$ and $v(\mathrm{C}-\mathrm{N})$. This was further supported by a band observed in the region $\sim 510 \mathrm{~cm}^{-1}$. Additional support for the formation of a mixed ligand complex, coordination of the primary ligand $\mathrm{L} 1$ and secondary ligand $\mathrm{L} 2$ and the solvent was suggested by the four bands observed in the region $\sim 600 \mathrm{~cm}^{-1}$. These were attributed to metal-oxygen and metal-nitrogen stretching frequency (Table 1) [32].

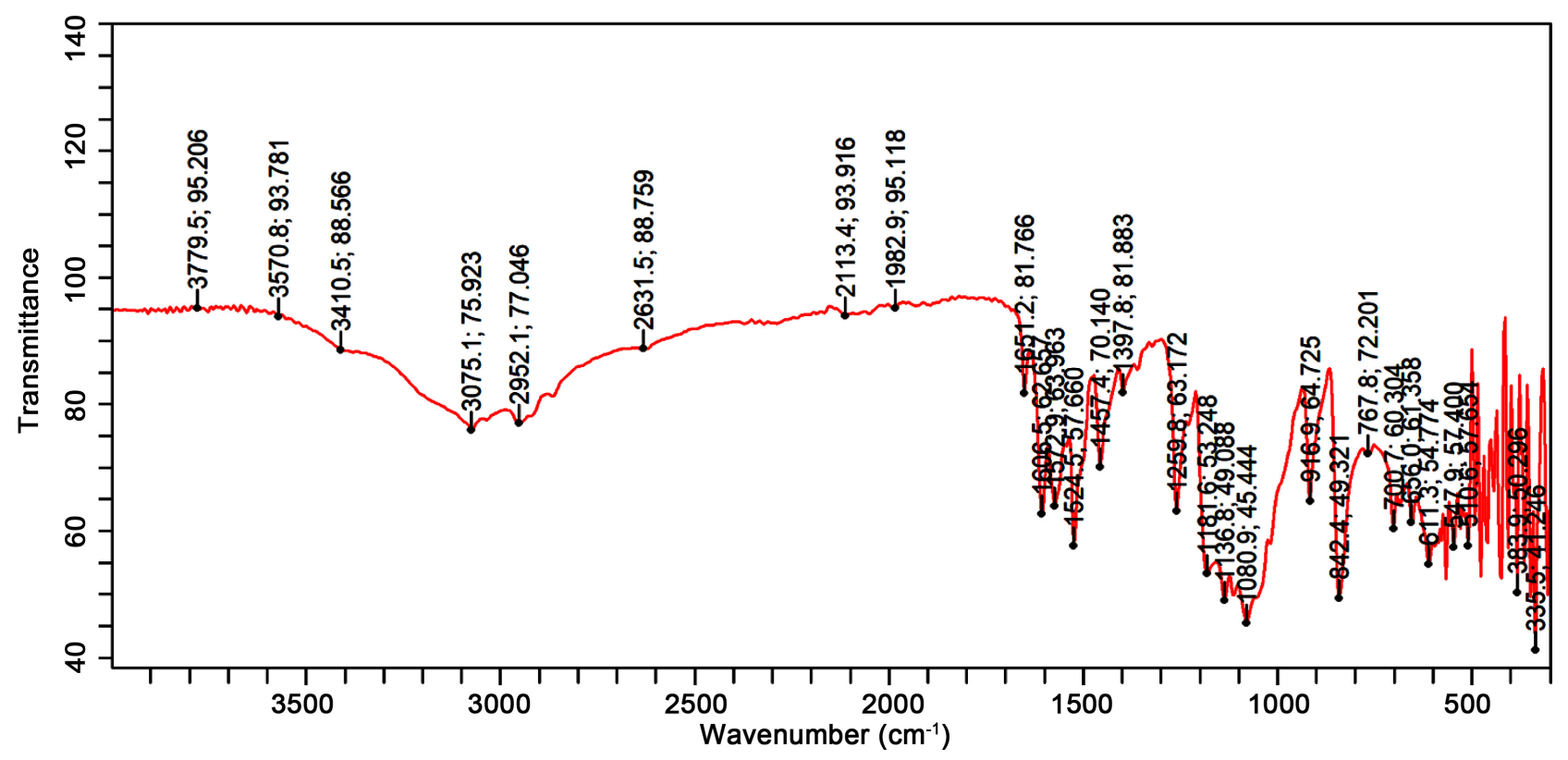

Figure 3. FTIR spectrum of compound 2. 
Table 1. Relevant infrared spectra bands for the ligands and complexes $\left(\mathrm{cm}^{-1}\right)$.

\begin{tabular}{|c|c|c|c|c|c|c|c|c|}
\hline & L1 & L2 & 1 & $2 \mathrm{~cm}^{-1}$ & 3 & 4 & 5 & 6 \\
\hline$v(\mathrm{O}-\mathrm{H})$ & 3330 & & 3358,3242 & 3779,3570 & 3358,3246 & 3205 & 3459 & 3380 \\
\hline$v(\mathrm{C}-\mathrm{OH})$ & 2100 & & 2113 & 2113 & 2117 & 2120 & 2117 & 2158 \\
\hline$v(\mathrm{C}=\mathrm{O})+v(\mathrm{C}=\mathrm{C})$ & 1650,1530 & & 1613,1558 & 1651,1574 & 1644,1558 & 1661,1555 & 1640,1558 & 1660,1599 \\
\hline$v(\mathrm{C}=\mathrm{O})+\delta(\mathrm{C}-\mathrm{H})$ & 1630,1450 & & 1457 & 1606,1457 & 1613,1457 & 1605,1457 & 1606,1457 & 1546,1461 \\
\hline$\delta(\mathrm{O}-\mathrm{H}) \mathrm{Ar}$ & 1250 & & 1394 & 1397 & 1394 & 1364 & 1397 & 1383 \\
\hline$v(\mathrm{C}-\mathrm{O}-\mathrm{C})$ & 1230 & & 1282,1252 & 1259,1181 & 1289,1190 & 1244 & 1289 & 1274,1203 \\
\hline$v(\mathrm{~N}-\mathrm{H})$ & & & & 3410 & & 3104 & & 3116,3063 \\
\hline$\delta(\mathrm{N}-\mathrm{H})$ & & 3340 & & 1524 & & 1401 & & 1494 \\
\hline$v(\mathrm{C}-\mathrm{N})$ & & 1590,1420 & & 1136 & & 1182 & & 1092 \\
\hline$\delta(\mathrm{O}-\mathrm{H})$ & & 1180 & 1073,1021 & 1080 & 1073,1021 & 1069,1013 & 1066,1013 & 1039 \\
\hline$v(\mathrm{M}-\mathrm{O})$ & & & 685 & 656,611 & 685 & 685 & 685,568 & 629 \\
\hline$v(\mathrm{M}-\mathrm{N})$ & & & & 547,510 & & 520 & & 536 \\
\hline
\end{tabular}

3) Compound 3: This spectrum exhibited two bands at 3358 and $3246 \mathrm{~cm}^{-1}$, which are ascribable to $v(\mathrm{O}-\mathrm{H})$ (Figure 4). Similar to what was obtained for compound 2, the higher frequency band was ascribed to the phenolic $v(\mathrm{O}-\mathrm{H})$ which is supported by the appearance of the $\delta(\mathrm{O}-\mathrm{H}) \mathrm{Ar}$ at $1394 \mathrm{~cm}^{-1}$. The lower frequency band was attributed to an additional $v(\mathrm{O}-\mathrm{H})$ from the solvent. Bands observed at 1073 and $1021 \mathrm{~cm}^{-1}$ due to $\delta(\mathrm{O}-\mathrm{H})$, served as evidence in support of this. Coordination of the carbonyl oxygen atom to the central metal ion was suggested by the shifts in the $(\mathrm{C}=\mathrm{O})+v(\mathrm{C}=\mathrm{C})$ at 1613 and $1558 \mathrm{~cm}^{-1}$ and the $v(\mathrm{C}=\mathrm{O})+\delta(\mathrm{C}-\mathrm{H})$ at $1457 \mathrm{~cm}^{-1}$. Bands observed at 685,551 and $514 \mathrm{~cm}^{-1}$, attributable to $v(\mathrm{M}-\mathrm{O})$, suggested coordination to the central metal ion via three different atoms namely: two oxygen atoms from the carbonyl and phenol substituent of $\mathbf{L} 1$ and oxygen atoms from the solvent [32].

4) Compound 4: The $v(\mathrm{O}-\mathrm{H})$ was observed at 3205 and $3104 \mathrm{~cm}^{-1}$, assignable to the phenolic substituent of $\mathbf{L} 1$ and hydroxyl substituent from the solvent. Evidence in support of this was provided by frequency bands observed at 1364 and $1069,1013 \mathrm{~cm}^{-1}$ (Figure 5), which corresponds to $\delta(\mathrm{O}-\mathrm{H}) \mathrm{Ar}$ and $\delta(\mathrm{O}-\mathrm{H})$ respectively. This therefore, suggested the coordination of donor atoms from this substituent to the central metal ion. Shifts were observed for the bands $v(\mathrm{C}=\mathrm{O})+v(\mathrm{C}=\mathrm{C})$ to $1661,1555 \mathrm{~cm}^{-1}$ and $v(\mathrm{C}=\mathrm{O})+\delta(\mathrm{C}-\mathrm{H})$ to $1605,1457 \mathrm{~cm}^{-1}$. As such, indicating coordination of the ligand to the metal ion. Evidence for the coordination of the secondary ligand and the formation of a mixed ligand complex was provided by the band at $1182 \mathrm{~cm}^{-1}$ assigned to $\delta(\mathrm{N}-\mathrm{H})+v(\mathrm{C}-\mathrm{N})$. Bands observed at 685 , and $520 \mathrm{~cm}^{-1}$ were ascribed to $v(\mathrm{M}-\mathrm{O})$ and $v(\mathrm{M}-\mathrm{N})$ respectively. This suggested the coordination of both oxygen and nitrogen atoms to the central metal ion [32].

5) Compound 5: In the spectrum of compound 5 bands observed at 3459 and $3153 \mathrm{~cm}^{-1}$ were attributed to phenolic substituent of $\mathrm{L} 1$ and hydroxyl substituent from the solvent. The $\delta(\mathrm{O}-\mathrm{H}) \mathrm{Ar}$ was observed at $1397 \mathrm{~cm}^{-1}$ and $\delta(\mathrm{O}-\mathrm{H})$ at 1066 


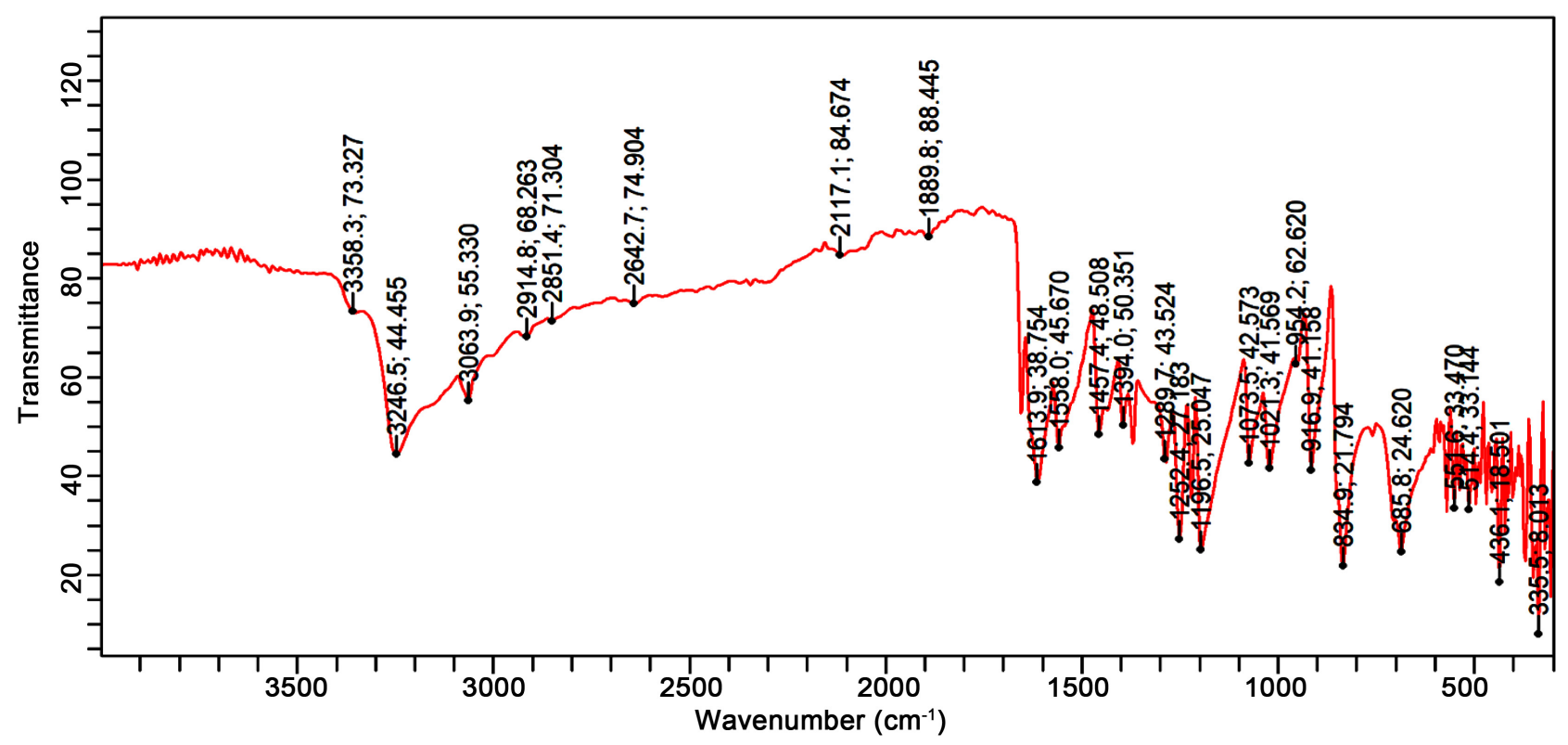

Figure 4. FTIR spectrum of compound 3.

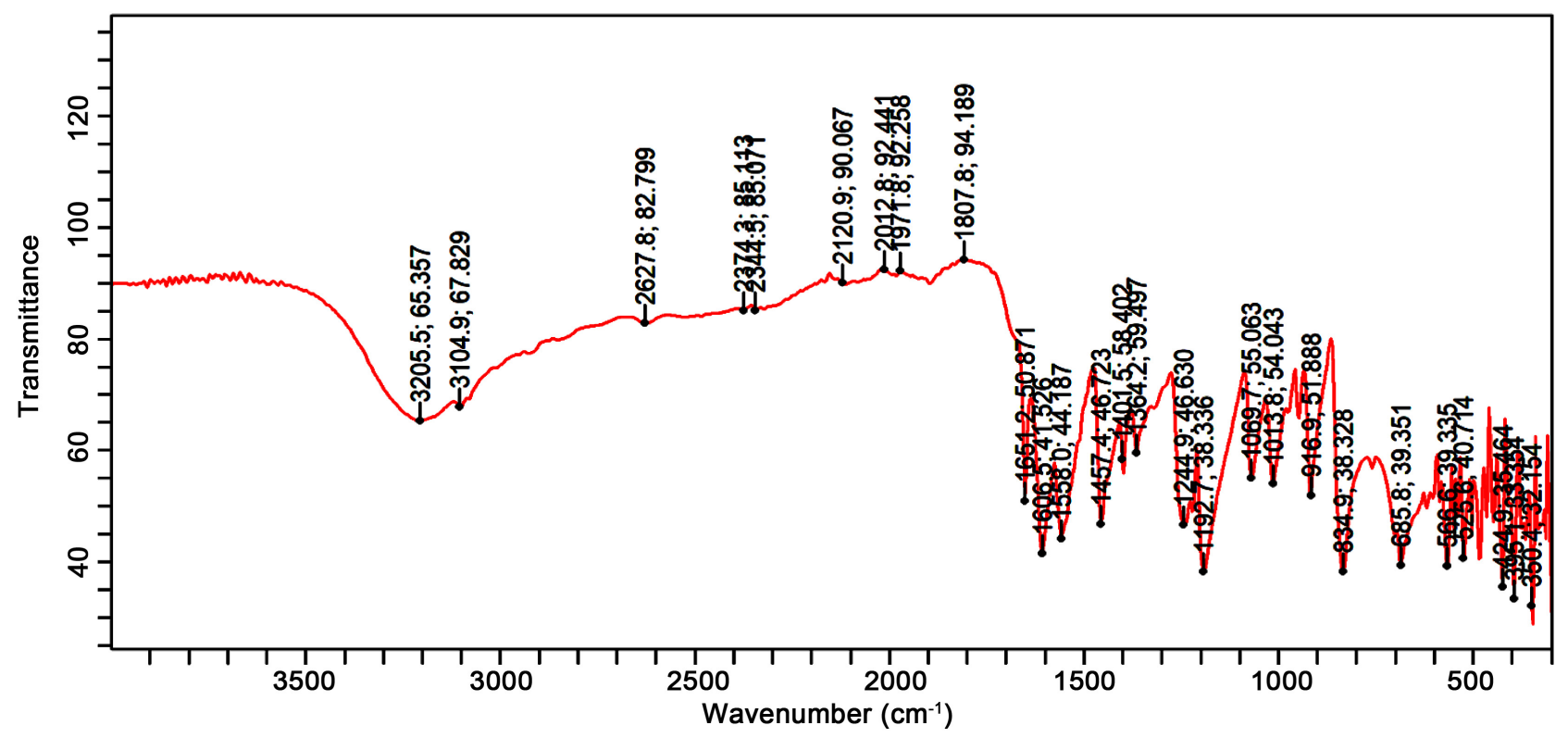

Figure 5. FTIR spectrum of compound 4.

and $1013 \mathrm{~cm}^{-1}$. In support of this was the $v(\mathrm{C}-\mathrm{OH})$ observed at $2117 \mathrm{~cm}^{-1}$ (Figure 6). The $v(\mathrm{C}=\mathrm{O})+v(\mathrm{C}=\mathrm{C})$ was observed at $1558 \mathrm{~cm}^{-1}$ while the $v(\mathrm{C}=\mathrm{O})$ $+\delta(\mathrm{C}-\mathrm{H})$ was observed at 1606 and $1457 \mathrm{~cm}^{-1}$. Coordination of the metal ion to the ligand was confirmed by the bands observed at 685 and $568 \mathrm{~cm}^{-1}$ [32].

6) Compound 6: Evidence obtained from the spectrum of compound 6 suggested the coordination of the phenolic substituent of L1 and hydroxyl substituent from the solvent (Table 1). In addition to this the formation of a mixed ligand complex was suggested by the appearance of double spike at 3116 and 3063 $\mathrm{cm}^{-1}$ (Figure 7). This may be attributed to the nitrogen-hydrogen stretching 


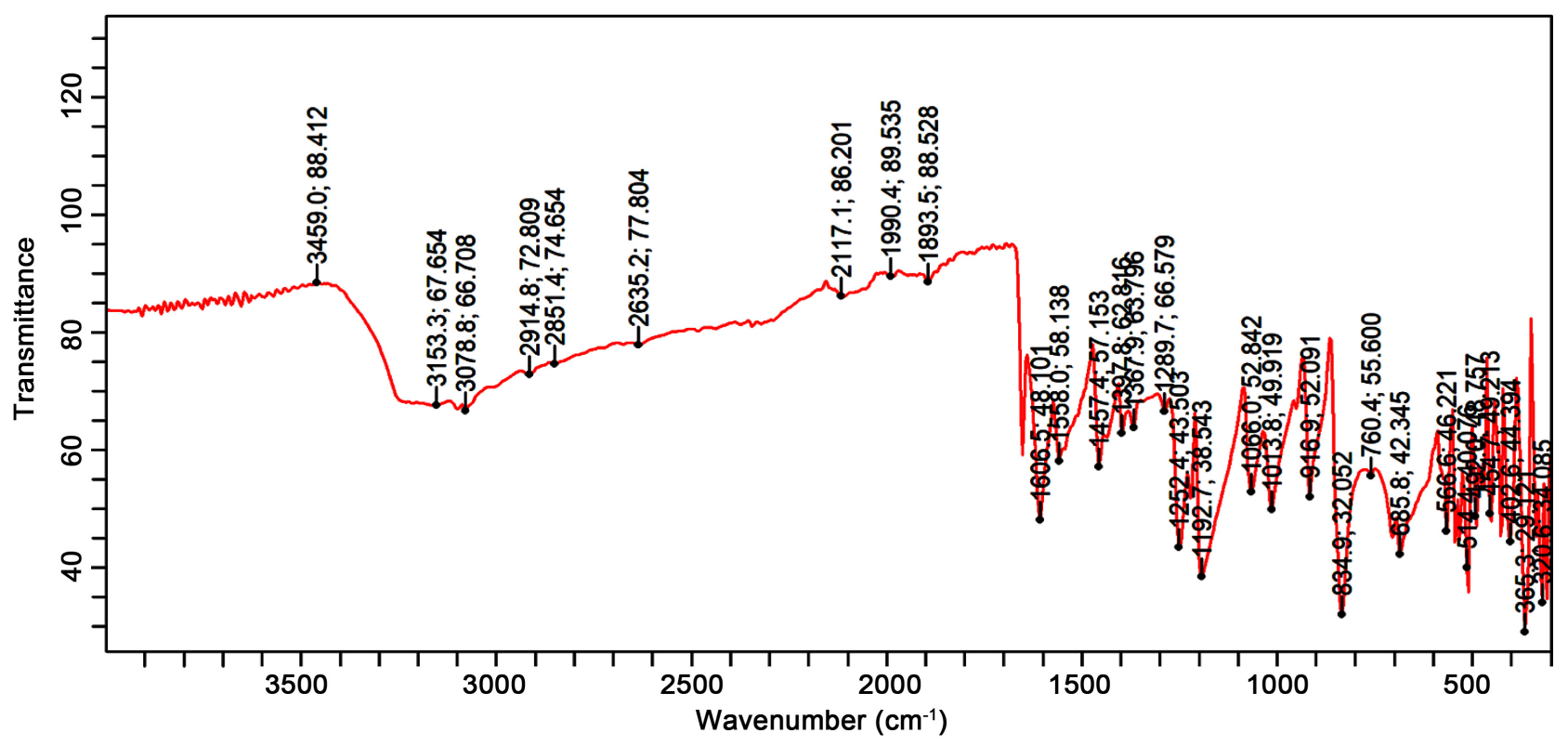

Figure 6. FTIR spectrum of compound 5.

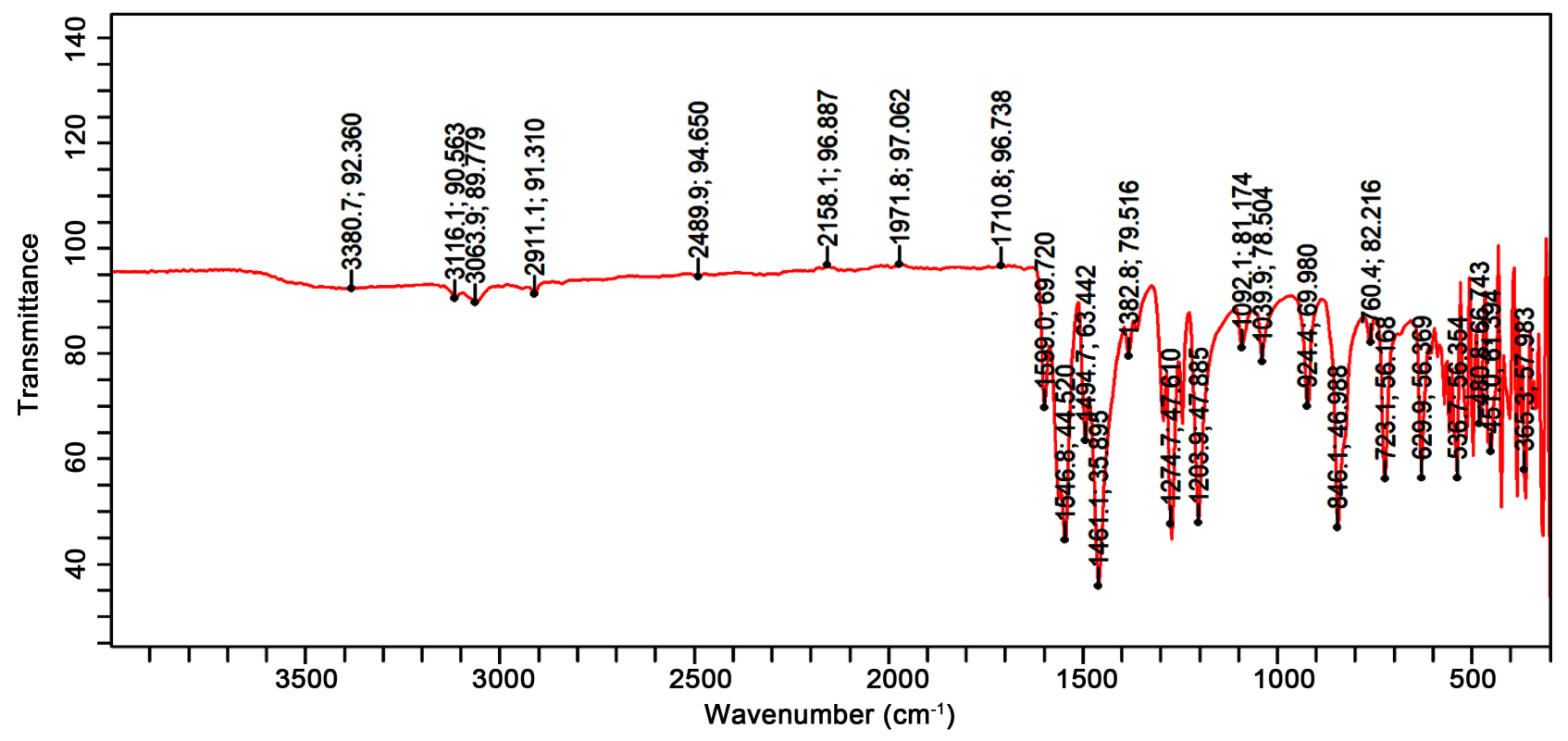

Figure 7. FTIR spectrum of compound 6.

frequency, from the $-\mathrm{NH}_{2}$ moiety. This was corroborated by the presence of medium bands at 1494 and $1092 \mathrm{~cm}^{-1}$ assignable to $\delta(\mathrm{N}-\mathrm{H})$ and $v(\mathrm{C}-\mathrm{N})$ frequency bands respectively. Bands observed at 629 and $536 \mathrm{~cm}^{-1}$ were ascribed to $v(\mathrm{M}-\mathrm{O})$ and $v(\mathrm{M}-\mathrm{N})$ respectively [32].

\subsection{Electronic Spectra}

1) Compound 1 and 2: The electronic spectra of compounds 1 and 2 exhibited three intense bands in the ultraviolet region respectively (Table 2). These were assigned to $\mathrm{n} \rightarrow \sigma^{\star}, \mathrm{n} \rightarrow \pi^{\star}$ and $\pi \rightarrow \pi^{\star}$ for compound 1 and $\mathrm{n} \rightarrow \sigma^{\star}, \mathrm{n} \rightarrow \pi^{\star}$ and $\pi$ 
$\rightarrow \pi^{\star}$ for compound 2 [30] [31]. The visible region revealed weak broad frequency bands 437 and $798 \mathrm{~nm}$ for compound 1 . These were assigned to ${ }^{6} \mathrm{~A}_{1 \mathrm{~g}} \rightarrow$ ${ }^{4} \mathrm{~T}_{1 \mathrm{~g}}$ and ${ }^{6} \mathrm{~A}_{1 \mathrm{~g}} \rightarrow{ }^{4} \mathrm{E}_{\mathrm{g}}$. For compound 2 the visible region exhibited bands at 626 and $717 \mathrm{~nm}$ ascribable to ${ }^{6} \mathrm{~A}_{1 \mathrm{~g}} \rightarrow{ }^{4} \mathrm{~T}_{2 \mathrm{~g}}$ and ${ }^{6} \mathrm{~A}_{1 \mathrm{~g}} \rightarrow{ }^{4} \mathrm{E}_{\mathrm{g}}$. Iron(III) ion in an octahedral environment has a $\Phi$ configuration with a spin only magnetic moment of $5.92 \mathrm{BM}$ [33]. Compounds 1 and 2 exhibited a magnetic moment of 6.83 and 6.45 $\mathrm{BM}$, respectively. Both are consistent with an octahedral geometry and therefore corroborates the results obtained for their electronic spectra [33] [34].

2) Compound 3 and 4: The spectrum for compound 3 elicited an intense band at $275 \mathrm{~nm}$ (Table 2) assigned to $\mathrm{n} \rightarrow \pi^{*}$ transition. The spectrum for compound 4 however exhibited bands at 224,274, 307 and $326 \mathrm{~nm}$ corresponding to $\mathrm{n} \rightarrow \sigma^{*}, \mathrm{n}$ $\rightarrow \pi^{\star}$ and $\pi \rightarrow \pi^{*}, \pi \rightarrow \pi^{*}$ transitions [30] [31]. The visible spectrum for compound 3 showed frequency bands at 444, 607 and $760 \mathrm{~nm}$ which were given the assignment ${ }^{1} \mathrm{~A}_{1 \mathrm{~g}} \rightarrow{ }^{1} \mathrm{~T}_{2 \mathrm{~g}},{ }^{1} \mathrm{~A}_{\mathrm{lg}} \rightarrow{ }^{1} \mathrm{~T}_{\mathrm{lg}}$ and ${ }^{1} \mathrm{~A}_{\mathrm{lg}} \rightarrow{ }^{1} \mathrm{E}_{\mathrm{g}}$. On the other hand the spectrum of compound 4 showed bands at 824 and $878 \mathrm{~nm}$ and ascribed to ${ }^{1} \mathrm{~A}_{1 \mathrm{~g}} \rightarrow{ }^{1} \mathrm{E}_{\mathrm{g}}$ and ${ }^{1} \mathrm{~A}_{1 \mathrm{~g}} \rightarrow{ }^{1} \mathrm{~A}_{2 \mathrm{~g}} d$ - $d$ transitions [33] [34]. Cobalt(III) ion in an octahedral environment has a $d^{b}$ configuration, with a spin only magnetic moment of 4.84 BM. Compounds 3 and 4 elicited magnetic moment of 5.22 and 5.82 BM respectively. This is in agreement with previous reports and the high values obtained in comparison with the spin only values may be attributed to orbital contribution [33] [34].

3) Compound 5 and 6: The electronic spectrum of compound 5 showed four bands in the visible region at 416, 592,760 and $803 \mathrm{~nm}$ assigned to ${ }^{4} \mathrm{~A}_{2 \mathrm{~g}}(\mathrm{~F}) \rightarrow$ ${ }^{4} \mathrm{~T}_{1 \mathrm{~g}}(\mathrm{~F}),{ }^{4} \mathrm{~A}_{2 \mathrm{~g}}(\mathrm{~F}) \rightarrow{ }^{4} \mathrm{~T}_{2 \mathrm{~g}}(\mathrm{~F}),{ }^{4} \mathrm{~A}_{2 \mathrm{~g}}(\mathrm{~F}) \rightarrow{ }^{4} \mathrm{~T}_{\mathrm{lg}}(\mathrm{P})$ and ${ }^{4} \mathrm{~A}_{2 \mathrm{~g}}(\mathrm{~F}) \rightarrow{ }^{1} \mathrm{E}_{\mathrm{g}} \mathrm{d}-\mathrm{d}$ transitions respectively [33]. On the other hand Compound 6 elicited two broad at 430 and $601 \mathrm{~nm}$, which were attributed to ${ }^{4} \mathrm{~A}_{2 \mathrm{~g}}(\mathrm{~F}) \rightarrow{ }^{4} \mathrm{~T}_{1 \mathrm{~g}}(\mathrm{P})$ and ${ }^{4} \mathrm{~A}_{2 \mathrm{~g}}(\mathrm{~F}) \rightarrow{ }^{4} \mathrm{~T}_{1 \mathrm{~g}}(\mathrm{~F})$ transitions. The ultraviolet region exhibited three intense bands at 220, 270 and 360 $\mathrm{nm}$ for compound 6 [30] [31]. These were ascribed to $\mathrm{n} \rightarrow \sigma^{\star}, \mathrm{n} \rightarrow \pi^{\star}$ and $\pi \rightarrow \pi^{*}$ transitions [30] [31]. Compound 5 on the other hand elicited two intense bands in the ultraviolet region at 269 and $215 \mathrm{~nm}$, attributable to $\mathrm{n} \rightarrow \pi^{*}$ and $\pi \rightarrow \pi^{*}$ transitions [30] [31]. Magnetic moment of 3.76 and 3.33 BM was obtained for compounds 5 and 6 respectively. Both values are consistent with octahedral geometry. Although this is lower than the spin only magnetic moment for chromium(III) ion in an octahedral environment, 3.87 BM, this may be as a result of antiferromagnetism [33] [34].

Based on the results obtained it is suggested that $\mathrm{L} 1$ coordinated in a bidentate fashion coordinating to the metal ion via the oxygen atoms of the phenol moiety and the carbonyl substituent. On the other hand L2 coordinated using both nitrogen atoms of its amino substituents. Typically, $v(\mathrm{O}-\mathrm{H})$ ought to exhibit two bands in the high energy region, indicating symmetric and asymmetric stretch. Two bands were observed within this range for this vibrational frequency. However, the presence of both $(\mathrm{O}-\mathrm{H}) \mathrm{Ar}$ and $\delta(\mathrm{O}-\mathrm{H})$ suggested the coordination of the oxygen atom from the hydroxyl substituent of the solvent. This was further supported by the results obtained from the electronic spectra. The result obtained 
Table 2. Relevant electronic spectra bands (nm), for the ligands and complexes.

\begin{tabular}{ccc}
\hline COMPOUND & $\begin{array}{c}\text { Bands 1, 2, 3, } \\
\mathrm{nm}\end{array}$ & $\mathrm{d}-\mathrm{d}$ \\
& 207,316 & - \\
L1 & 202,324 & - \\
Compound 1 & $214,301,370$. & 437,798 \\
Compound 2 & $239,302,318$ & 626,717 \\
Compound 3 & 275 & $444,607,760$ \\
Compound 4 & $224,274,307,326$ & 824,878 \\
Compound 5 & 269,315 & $416,592,760,803$ \\
Compound 6 & $220,270,360$ & 430,601 \\
\hline
\end{tabular}

suggested octahedral geometry for all the complexes. Although compounds 1, 3 and 5 were designed as binary complexes, with M:L1 of (1:2). However, ternary complexes were obtained, with additional water molecules coordinated to the central metal ions, to attain octahedral geometry (Figure 8). For the mixed ligand complexes ternary complexes were designed with M:L1:L2, 1:1:1. However, in this case, coordination of the primary and secondary ligands occurred as well as coordination of two molecules of water to give an octahedral geometry (Figure 9). These were suggested from the infrared and electronic spectra of the compounds in addition to the magnetic moment and percentage metal concentration obtained for the compounds. The obtained percentage metal composition was in good agreement with the calculated values. The octahedral geometry assumed by the compounds served as an indication of the stability of the octahedral geometry for the central metal ions. Iron(III), cobalt(III) and chromium(III) have $d^{5}, d^{b}$ and $d^{\beta}$ configurations respectively, electron distribution will therefore favour partially-, singly- or fully-filled sub-shells, as a result of stability. Therefore, generally, with few exceptions, these metal ions in their +3 oxidation states assume the octahedral geometry.

\subsection{Cytotoxicity}

Although there are many methods used in the study of anticancer activity, brine shrimp lethality assay serves as a preliminary assay for the cytotoxici abilities for probable potent compounds [35] [36]. Brine shrimp lethality assay of the synthesized compounds and ligands was carried out, and the result obtained indicated that both ligands, the synthesized compounds and the metal salts were less potent in comparison with the standard $\mathrm{K}_{2} \mathrm{Cr}_{2} \mathrm{O}_{7}\left(\mathrm{LC}_{50} 5.56 \mu \mathrm{g} / \mathrm{ml}\right)$. However, both ligands exhibited significant $(P<0.05)$ cytotoxic activity with L1 and L2 exhibiting $\mathrm{LC}_{50}$ of 14.42 and $13.39 \mu \mathrm{g} / \mathrm{ml}$ respectively. This indicated $\mathrm{L} 2$ was the more active of the ligands and is in good agreement with previous studies. The chloride salt of iron(III), cobalt(III) and chromium(III) also elicited reasonable cytotoxic activity with $\mathrm{LC}_{50} 9.73,12.88$ and $12.62 \mu \mathrm{g} / \mathrm{ml}$ respectively. The order of activity for the compounds was $\mathbf{4}>\mathbf{1}>\mathbf{6}>\mathbf{3}>\mathbf{2}>\mathbf{5}$ with $\mathrm{LC}_{50} 33.53,36.15$, 


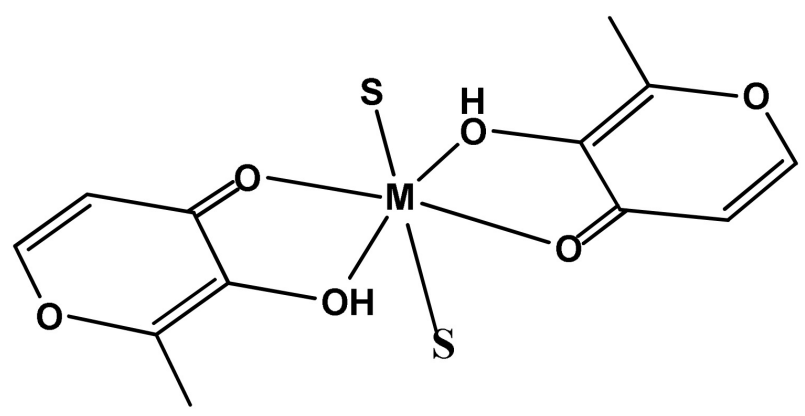

Figure 8. Structural representation for compound 1, 3 and 5 (M-Fe(III), $\mathrm{Co}(\mathrm{III})$ and $\mathrm{Cr}(\mathrm{III})$ and $\mathrm{S}=\mathrm{H}_{2} \mathrm{O}$ ).

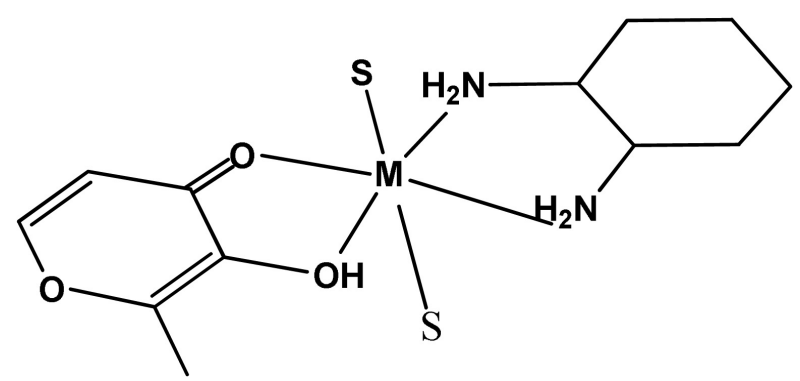

Figure 9. Structural representation for compound 2, 4 and 6 (M-Fe(III), $\mathrm{Co}(\mathrm{III})$ and $\mathrm{Cr}(\mathrm{III})$ and $\mathrm{S}=\mathrm{H}_{2} \mathrm{O}$ ).

$38.31,41.89,53.25$ and $64.51 \mu \mathrm{g} / \mathrm{ml}$. The mixed ligand complexes exhibited better active in comparison to their binary ligand counterparts. However compound 2, was an exception to this. In this case the ternary complex compound 1 was more cytotoxic than the mixed ligand complex, compound 2 . Since the result from the structural characterization indicated that all the compounds assumed similar geometry, this difference may be ascribed to the size of the $\mathrm{Fe}(\mathrm{III})$. Generally it may be inferred that chelation reduced the toxicity of the ligand and metal ion [37].

\subsection{Antioxidant Activity}

It is widely recognized that many of today's diseases are due to the oxidative stress that results from an imbalance between formation of ROS/RNS and their neutralization when endogenous antioxidant mechanisms are unable to quench the free radicals [8] [9] [10]. The free radicals are known to be scavenged by antioxidants; therefore, the search for effective antioxidants has become crucial. However, the determination of the total antioxidant activity of a compound is a complex procedure with varying chemical diversity [8] [38]. This usually occurs through several mechanisms which are influenced by many factors, which cannot be fully described with one single method. Therefore, it is essential to perform more than one type of antioxidant capacity measurement to take into account the various mechanisms of antioxidant action [38] [39] [40] [41]. In this study, four complementary tests were used to assess the antioxidant activity of compounds 1-6 viz.: inhibition of nitric oxide radical, determination of ferric 
reducing antioxidant power (FRAP), ferrous ion-chelating ability and cupric ion reducing antioxidant capacity assays.

1) Inhibition of nitric oxide radical: Nitric oxide is a diffusible free radical which acts as an effector molecule in a large number of biological processes [8] [42]. Conversely, excessive production and release of NO is reported to be linked to cytotoxicity. NO is generated in biological tissues by specific nitric oxide synthase which metabolize arginine to citrulline with the formation of NO via a five electron oxidative reaction. NO has been shown to be directly scavenged by phenolic compounds [8] [42] [43]. In this assay nitric oxide, generated from sodium nitroprusside in aqueous solution at physiological $\mathrm{pH}$, interacts with oxygen to produce nitrite ions which was measured by Griess reaction. Therefore, this is a hydrogen atom transfer (HAT)-based assay. Compounds 1-6 exhibited good NO scavenging activity leading to the reduction of the nitrate concentration in the assay medium. The order of potency is given by $2>4>1>6>5>3$. The NO scavenging capacity was concentration dependent with $1.00 \mathrm{mg} / \mathrm{ml} \mathrm{sca-}$ venging most efficiently. Compound 2 significantly $(P<0.05)$ inhibited the accumulation of nitrite (Table 3 ) and was the most comparable to the standard, ascorbic acid with $61.95 \mu \mathrm{g} / \mathrm{ml}$.

2) Ferrous Ion-chelating Ability: Iron chelating activity is one of the major characteristics of antioxidants [13]. Elevated levels of iron have been implicated in changing hydrogen peroxide ion, which is less reactive to hydroxyl radical, a highly toxic free radical and thereby inducing oxidative stress [8] [43]. In view of the aforementioned effects of iron overload, the manufacture of drugs to combat this challenge would be a promising strategy to ameliorate the consequences of oxidative stress and as well reduce the concentration of transition metals as catalysts of lipid peroxidation [8] [43]. From the results, all the synthesized compounds generally exhibited above average activity $(>50 \%)$. However, the compounds were not as potent as EDTA, the standard. Although compounds 3 and 4 demonstrated good chelating abilities eliciting as much as $73.77 \%$ and $68.21 \%$ inhibition respectively at $1 \mathrm{mg} / \mathrm{ml}$ comparable with the standard (Table 4). The order of activity was observed as $3>4>6>2>1>5$.

3) Determination of ferric reducing antioxidant power FRAP: The principle of this method is based on the reduction of a colourless ferric-tripyridyltriazine

Table 3. Nitric oxide radical inhibition ability of the compounds.

\begin{tabular}{ccc}
\hline COMPOUND & $\mathrm{IC}_{50} \mathrm{mg} / \mathrm{ml}$ & $\mathrm{SD}$ \\
\hline 1 & 0.284698 & 0.047563 \\
2 & 0.090803 & 0.090803 \\
3 & 0.662841 & 0.00778 \\
4 & 0.255575 & 0.014514 \\
5 & 0.491158 & 0.034967 \\
6 & 0.442303 & 0.073886 \\
\hline
\end{tabular}


Table 4. Ferrous ion-chelating ability of the compounds.

\begin{tabular}{ccc}
\hline COMPOUND & $\mathrm{IC}_{50} \mathrm{mg} / \mathrm{ml}$ & $\mathrm{SD}$ \\
\hline 1 & 0.862350 & 0.019409 \\
2 & 0.756028 & 0.162445 \\
3 & 0.247960 & 0.043982 \\
4 & 0.253974 & 0.024686 \\
5 & 0.880904 & 0.01479 \\
6 & 0.495694 & 0.125835 \\
\hline
\end{tabular}

Table 5. Ferric reducing antioxidant power (FRAP) of the compounds based on ascorbic acid equivalent.

\begin{tabular}{ccc}
\hline COMPOUNDS & AAE $\mathrm{mg} / \mathrm{g}$ & $\mathrm{SD}$ \\
\hline 1 & 0.206021 & 0.045782 \\
2 & 0.174131 & 0.043701 \\
3 & 0.151175 & 0.057349 \\
4 & 1.036674 & 0.021189 \\
5 & 0.226227 & 0.062259 \\
6 & 0.390488 & 0.033342 \\
\hline
\end{tabular}

Table 6. Cupric ions reducing ability of compounds expressed as trolox equivalent.

\begin{tabular}{ccc}
\hline COMPOUND & Te $\mathrm{mg} / \mathrm{g}$ & $\mathrm{SD}$ \\
\hline 1 & 0.712953 & 0.263589 \\
2 & 0.757745 & 0.248222 \\
3 & 0.8324 & 0.095114 \\
4 & 0.868234 & 0.095395 \\
5 & 0.68757 & 0.118905 \\
6 & 0.744308 & 0.333806 \\
\hline
\end{tabular}

complex to its blue ferrous coloured form owing to the action of electron donation in the presence of antioxidants [8] [28]. The compounds were observed as the ferric-tripyridyltriazine complex in a dose-dependent manner. Compound 4 elicited the highest activity of $1.03 \mathrm{mg} / \mathrm{g}$. The order at which the complex was reduced by the compounds was observed as $4>6>5>1>2>3$ (Table 5).

4) Cupric ion reducing antioxidant capacity (CUPRAC): In a comprehensive review by Prior et al. the authors classified CUPRAC as one of the electron-transfer based methods, and also summarize the superiorities of the CUPRAC method over other antioxidant assays [44]. The chromogenic oxidizing reagent bis(neocuproine)copper(II) chloride $(\mathrm{Cu}(\mathrm{II})-\mathrm{Nc})$, reacts with the antioxidants agent. In this reaction, the reactive Ar-OH groups of polyphenolic antioxidants are oxidized to the corresponding quinones (ascorbic acid is oxidized to dehydroascorbic acid) [44]. In this reaction compound 4 exhibited the highest potency with a Trolox equivalent of 0.86 (Table 6). All the compounds exhibited 
generally significant activity $(P<0.05)$ with order of reactivity observed as $4>$ $3>2>6>1>5$.

From the results obtained for both biological analyses, compound 4 elicited the best cytotoxic activity. Additionally, it exhibited the best antioxidant activity for two of the four essays and the second best for the other two. It may therefore be inferred from these results that a good cytotoxic agent may also have antioxidant activity. Further studies are however suggested to ascertain their complementary effect.

\section{Conclusion}

The result obtained demonstrated the relative stability of the octahedral geometry for iron(III), cobalt(III) and chromium(III). It was suggested that two molecules of the solvent coordinated to the metal ions in addition to the ligands to attain octahedral geometry. Both the primary and secondary ligands coordinated in a bidentate fashion. The primary ligand 3-Hydroxy-2-methyl-4H-pyran-4-one coordinated using the oxygen atom of its phenolic substituent and the oxygen atom of the carbonyl, to act as an $O O$ ligand. The results obtained also suggested that the phenolic substituent was not deprotonated prior to coordination. Therefore $\mathbf{L} 1$ acted as a neutral ligand. The secondary ligand 1,2-diaminocyclohexane also coordinated using both nitrogen atoms of its amino substituent. The synthesized compounds exhibited moderate cytotoxicity, although they were not as active as the standard. The cobalt(III) mixed ligand complex elicited the highest activity and also antioxidant activity.

\section{Conflicts of Interest}

The author declares no conflicts of interest regarding the publication of this paper.

\section{References}

[1] Lu, J.W., Huang, Y.H., Lo, S.I. and Wein, H.H. (2007) New $\mu$-Oxo-Bridged Tetranuclear Cu(II) Complex with Schiff-Base Ligand: Synthesis, Crystal Structure and Magnetic Properties. Inorganic Chemistry Communications, 10, 1210-1213. https://doi.org/10.1016/j.inoche.2007.07.009

[2] Ferell, N.P. (2003) Metal Complexes as Drugs and Chemotherapeutic Agents. In: Comprehensive Coordination Chemistry II, Volume 9, Elsevier, Amsterdam, 809-847.

[3] Haas, K.L. and Franz, K.J. (2009) Application of Metal Coordination Chemistry to Explore and Manipulate Cell Biology. Chemical Review, 109, 4921-4960. https://doi.org/10.1021/cr900134a

[4] Phillips, A.A., Oguntunde, O.A. and Afolayan, O.M. (2015) Cancer Mortality Pattern in Lagos University Teaching Hospital, Lagos, Nigeria. Journal of Cancer Epidemiology, 2015, Article ID: 842032. https://doi.org/10.1155/2015/842032

[5] Ferlay, J., Shin, H., Bray, F., Frman, D., Mathers, C. and Parkin, D.M. (2008) Cancer Incidence and Mortality Worldwide. Globacan-v1.2, IARC Cancer, Base No. http://globocan.iarc.fr

[6] Syahmi, A., Vijayarathna, S., Sasidharan, S., Latha, L., Kwan, Y., Lau, Y., Shin, L. 
and Chen, Y. (2010) Acute Oral Toxicity and Brine Shrimp Lethality of Elaeis guineensis Jacq., (Oil Palm Leaf) Methanol Extract. Molecules, 15, 8111. https://doi.org/10.3390/molecules15118111

[7] Elsyana, V., Bintang, M. and Priosoeryanto, N. (2016) Cytotoxicity and Antiproliferative Activity Assay of Clove Mistletoe (Dendrophthoe pentandra (L.) Miq.) Leaves Extracts. Advances in Pharmacological Sciences, 2016, Article ID: 3242698. https://doi.org/10.1155/2016/3242698

[8] ElJemli, M., Kamal, R., Marmouzi, I., Zerrouki, A., Cherrah, Y. and Alaoui, K. (2016) Radical-Scavenging Activity and Ferric Reducing Ability of Juniperus thurifera (L.), J. oxycedrus (L.), J. phoenicea (L.) and Tetraclinis articulata(L.). Advances in Pharmacological Sciences, 2016, Article ID: 6392656.

https://doi.org/10.1155/2016/6392656

[9] Pham-Huy, L.A., He, H. and Pham-Huy, C. (2008) Radicals, Antioxidants in Disease and Health. International Journal of Biomedical Science, 4, 89-96.

http://www.ijbs.org

[10] Pizzino, G., Irrera, N., Cucinotta, M., Pallio, G., et al. (2017) Oxidative Stress: Harms and Benefits for Human Health. Oxidative Medicine and Cellular Longevity, 2017, Article ID: 8416763. https://doi.org/10.1155/2017/8416763

[11] Robu, S., Aprotosoaie, A.C., Miron, A., Cioancă, O., et al (2012) In Vitro Antioxidant Activity of Ethanolic Extracts from Some Lavandula Species Cultivated in Romania. Farmacia, 60, 394-401.

[12] Sznarkowska, A., Kostecka, A., Meller, K. and Bielawski, K. (2017) Inhibition of Cancer Antioxidant Defense by Natural Compounds. Oncotarget, 8, 15996-16016. https://doi.org/10.18632/oncotarget.13723

[13] Singh, K., Bhori, M., Kasu, Y.A., Bhat, G. and Marar, T. (2018) Antioxidants as Precision Weapons in War against Cancer Chemotherapy Induced Toxicity-Exploring the Armoury of Obscurity. Saudi Pharmaceutical Journal, 26, 177-190. https://doi.org/10.1016/j.jsps.2017.12.013

[14] Ilghami, R., Barzegari, A., Mashayekhi, M.R., Letourneur, D., Crepin, M. and Pavon-Djavid, G. (2020) The Conundrum of Dietary Antioxidants in Cancer Chemotherapy. Nutrition Reviews, 78, 65-76.

[15] Uttara, B., Singh, A.V., Zamboni, P. and Mahajan, R.T. (2009) Oxidative Stress and Neurodegenerative Diseases: A Review of Upstream and Downstream Antioxidant Therapeutic. Current Neuropharmacology, 7, 65-74. https://doi.org/10.2174/157015909787602823

[16] Habu, J.B. and Ibeh, B.O. (2015) In Vitro Antioxidant Capacity and Free Radical Scavenging Evaluation of Active Metabolite Constituents of Newbouldia laevis Ethanolic Leaf Extract. Biological Research, 48, 16.

https://doi.org/10.1186/s40659-015-0007-x

[17] Antolovich, M., Prenzier, P., Patsalides, E., McDonald, S. and Robards, K. (2002) Methods for Testing Antioxidant Activity. Analyst, 127, 183-198.

https://doi.org/10.1039/b009171p

[18] Amatori, S., et al. (2012) Synthesis, Basicity, Structural Characterization, and Biochemical Properties of Two [(3-Hydroxy-4-pyron-2-yl)methyl]amine Derivatives Showing Antineoplastic Features. The Journal of Organic Chemistry, 77, 2207-2218. https://doi.org/10.1021/jo202270j

[19] Amatori, S., et al. (2010) Malten, a New Synthetic Molecule Showing in Vitro Antiproliferative Activity against Tumour Cells and Induction of Complex DNA Structural Alterations. British Journal of Cancer, 103, 239-248. 
https://doi.org/10.1038/sj.bjc.6605745

[20] Rixe, O., Ortuzar, W., Alvarez, M., Parker, R., Reed, E., Paull, K. and Fojo, T. (1996) Oxaliplatin, Tetraplatin, Cisplatin, and Carboplatin: Spectrum of Activity in Drug-Resistant Cell Lines and in the Cell Lines of the National Cancer Institute's Anticancer Drug Screen Panel. Biochemical Pharmacology, 52, 1855-1865. https://doi.org/10.1016/S0006-2952(97)81490-6

[21] Gibbons, G.R., Wyrick, S. and Chaney, S.G. (1989) Rapid Reduction of Tetrachloro(D,L-trans)1,2-diaminocyclohexaneplatinum(IV) (Tetraplatin) in RPMI 1640 Tissue Culture Medium. Cancer Research, 49, 1402-1407.

[22] Bonire, J.J. and Fricker, S.P. (2001) The in Vitro Antitumour Profile of Some 1,2-Diaminocyclohexane Organotin Complexes. Journal of Inorganic Biochemistry, 83, 217-221. https://doi.org/10.1016/S0162-0134(00)00192-6

[23] Aiyelabola, T.O., Akinkunmi, E.O. and Akinade, A. (2020) Syntheses of Coordination Compounds of ( \pm )-2-Amino-3-(4-Hydroxyphenyl)Propionic Acid, Mixed Ligand Complexes and Their Biological Activities. Advances in Biological Chemistry, 10, 25-42. https://www.scirp.org/journal/abc https://doi.org/10.4236/abc.2020.102003

[24] Solis, P.N., Wright, C.W., Anderson, M.M., Gupta, M.P. and Phillipson, J.D. (1993) A Microwell Cytotoxicity Assay Using Artemia salina (Brine Shrimp). Planta Medica, 59, 250-252. https://doi.org/10.1055/s-2006-959661

[25] Marcocci, L., Packer, L., Droy-Lefai, M.T., Sekaki, A. and Gardes-Albert, M. (1994) Antioxidant Action of Ginkgo biloba Extracts EGb 761. Methods in Enzymology, 234, 462-475. https://doi.org/10.1016/0076-6879(94)34117-6

[26] Benzie, I.F. and Strain, J.J. (1996) The Ferric Reducing Ability of Plasma (FRAP) as a Measure of "Antioxidant Power" the FRAP Assay. Analytical Biochemistry, 239, 70-76. https://doi.org/10.1006/abio.1996.0292

[27] Singh, N. and Rajini, P.S. (2004) Free Radical Scavenging Activity of an Aqueous Extract of Potato Peel. Food Chemistry, 85, 611-616.

https://doi.org/10.1016/j.foodchem.2003.07.003

[28] Apak, R., Guclu, K., Ozyurek, M., Karademir, S.E. and Altun, M. (2005) Total Antioxidant Capacity Assay of Human Serum Using Copper(II)-Neocuproine as Chromogenic Oxidant: The CUPRAC Method. Free Radical Research, 39, 949-961. https://doi.org/10.1080/10715760500210145

[29] Gulcin, I. (2012) Antioxidant Activity of Food Constituents: An Overview. Archives of Toxicology, 86, 345-391. https://doi.org/10.1007/s00204-011-0774-2

[30] Kemp, W. (1999) Organic Spectroscopy. 3rd Edition, Macmillan, Hong Kong, 19-98.

[31] Pavia, D., Lampman, G. and Kriz, G. (2001) Introduction to Spectroscopy, a Guide for Students of Organic Chemistry. 3rd Edition, Thomson Learning, Boston, 22-368.

[32] Nakamoto, K. (2009) Infrared and Raman Spectroscopy of Inorganic and Coordination Compounds: Applications in Coordination, Organometallics and Bioinorganic Chemistry. 6th Edition, John Wiley and Sons, New York, 67-69.

[33] Greenwood, N.N. and Earnshaw, A. (1997) Chemistry of the Elements. 2nd Edition, Butterworth-Heinemann, Hong Kong, 1060-1090, 1290-1326.

[34] Miessler Miessler, G.L. and Tarr, D.A. (1999) Inorganic Chemistry. Pearson Prentice Hall, New York, 315-316.

[35] Syahmi, A., Vijayarathna, S., Sasidharan, S., Latha, L., Kwan, Y., Lau, Y., Shin, L. 
and Chen, Y. (2010) Acute Oral Toxicity and Brine Shrimp Lethality of Elaeis guineensis Jacq., (Oil Palm Leaf) Methanol Extract. Molecules, 15, 8111-8121. https://doi.org/10.3390/molecules15118111

[36] Koch, S., Mayer, F., Honecker, F., Schittenhelm, M. and Bokemeyer, C. (2003) Efficacy of Cytotoxic Agents Used in the Treatment of Testicular Germ Cell-Tumors under Normoxic and Hypoxic Conditions In Vitro. British Journal of Cancer, 89, 2133-2139. https://doi.org/10.1038/sj.bjc.6601375

[37] Elsyana, V., Bintang, M. and Priosoeryanto, N. (2016) Cytotoxicity and Antiproliferative Activity Assay of Clove Mistletoe (Dendrophthoe pentandra (L.) Miq.) Leaves Extracts. Advances in Pharmacological and Pharmaceutical Sciences, 2016, Article ID: 3242698. https://doi.org/10.1155/2016/3242698

[38] Awah, F. and Verla, A.W. (2010) Antioxidant Activity, Nitric Oxide Scavenging Activity and Phenolic Contents of Ocimum gratissimum Leaf Extract. Journal of Medicinal Plants Research, 4, 2479-2487. https://doi.org/10.5897/JMPR10.262

[39] Schlesier, K., Harwat, M., Bohm, V. and Bitsch, R. (2002) Assessment of Antioxidant Activity by Using Different In Vitro Methods. Free Radical Research, 36, 177-187. https://doi.org/10.1080/10715760290006411

[40] Aruoma, O.I. (2003) Methodological Considerations for Characterizing Potential Antioxidant Actions of Bioactive Components in Plant Foods. Mutation Research-Fundamental and Molecular Mechanisms of Mutagenesis, 523-524, 9-20. https://doi.org/10.1016/S0027-5107(02)00317-2

[41] Wong, S.P., Leong, L.P. and Koh, J.H.W. (2006) Antioxidant Activities of Aqueous Extracts of Selected Plants. Food Chemistry, 99, 775-783.

https://doi.org/10.1016/j.foodchem.2005.07.058

[42] Boora, F., Chirisa, E. and Mukanganyama, S. (2014) Evaluation of Nitrite Radical Scavenging Properties of Selected Zimbabwean Plant Extracts and Their Phytoconstituents. Journal of Food Processing, 2014, Article ID: 918018. https://doi.org/10.1155/2014/918018

[43] Essuman, E.K., Nagajyothi, P.C. and Tettey, C.O. (2017) Antioxidant, Ferric Iron Chelation and Antimicrobial Activities of Extracts of Pseudocydonia sinensis (Chinese Quince). Fruit Journal of Medicinal Plants Studies, 5, 175-179.

[44] Apak, R., Gu, K., Mustafa, O. and Celik, S.E. (2008) Mechanism of Antioxidant Capacity Assays and the CUPRAC (Cupric Ion Reducing Antioxidant Capacity) Assay. Microchim Acta, 160, 413-419. https://doi.org/10.1007/s00604-007-0777-0 